\title{
DEVELOPMENT OF ENTREPRENEURSHIP AS A COMPONENT OF REGIONAL POLICY IN LATVIA
}

\author{
Meldra Gineite, Anastasija Vilcina \\ Latvia University of Agriculture
}

\begin{abstract}
Balanced regional development in Latvia is one of the most important issues on all political levels in terms of development strategy. In Latvia there are five planning regions - Kurzeme, Latgale, Vidzeme, Rīga, Zemgale. The regional development is not balanced. The most powerful region is Rīga, because significant part of economic activity takes place there, also most part of inhabitants live there. Consequently, it is important to have efficient regional policy, to ensure a balanced regional development.

In year 2009 important reform was realized in Latvia - administrative-territorial reform. As a result now there are 118 local governments (before reform - 548) in Latvia with the average population of 19100 (before reform 4 300) inhabitants. However, there are differences among the local governments - both in population and economic development. Part of the municipalities is classified as a mixed urban and rural area. Theoretically local municipalities have become more powerful; yet there are still discussions taking place whether this administrative-territorial reform was really necessary.

One of the concepts of sustainable development (which is also a principle of the regional policy) is that big amount of social and environmental problems could be solved by sector of entrepreneurship. Also development of regional economy is related to the local governments and its ability to use resources, create working places and promote and strengthen business activities. Entrepreneurship, its development is seen as basics of country's progress, because business creates work places, provide tax revenue and the output is goods and services. Business can be considered as one of the driving forces of society. Consequently development of entrepreneurship, its support should also be a component of regional policy. In the article authors are analyzing both the role of entrepreneurship in regional policy in Latvia and identifying differences of business development on regional level. Researchers in recent years have a lot of discussions, what kind of activities are necessary and what kind of regional policy is appropriated to balance entrepreneurial activity in different regions.

In Latvia regional policy is developing since recovery of independence in $\mathbf{1 9 9 0}^{\text {th }}$. Resuming planning document hierarchy in Latvia, it is possible to divide regulation of planning system in three levels: national level, regional level and local level. After the administrative territorial reform, controversies about necessity to strengthen the regional level in administrative way have intensified. In regulations there are also mentioned needs of business.

There exist significant economic differences between regions of Latvia. Coherence between region development and activity of entrepreneurship is also noted. It demonstrates that supporting development of entrepreneurship and motivating people to start their own business, also providing suitable business environment and successful realization of support activities could also be a useful instrument of regional policy.
\end{abstract}

Keywords: Entrepreneurship, economic, regional differences, regional development, policy.

\section{Introduction}

Regional policy is one of the most complicated issues for policy makers both on national and global level. Traditionally regional policy means to realize purposive activities to coordinate development of different sectors to support and promote progress of separate territory parts. Regional development is focused on balancing and sustaining development of territory. Any regional policy has two aspects - economic and social. It means that policy makers need to correct free market economy to achieve two interconnected aims - development of economic and social equality and prosperity. In practice implementation of regional policy means that government intervenes in the private sector.

One of the regional policy components is regional economic development policy, and its aim is to reduce socio-economic disparities between areas and territories. Development of economy is closely related to entrepreneurship. Entrepreneurship plays an important role in stimulating region's economic development and growth (Hackler,Mayer, 2008). In recent years entrepreneurship has become one of the instruments to solve certain social problems. Entrepreneurs have to play more and more roles. Entrepreneurship as an all-embracing concept appears to be the most prominent solution for a better society, economically as well as socially (Johansson, 2009). Economic strength and business vitality as well as innovative capacity, entrepreneurial environment, creative class, and liveability (Barkley, 2008) also are related with regional competitiveness.

All these issues indicate that entrepreneurship has a great impact on regional development as well as success of development of some industry or enterprises in general could be associated with the regional policy.

Regional development and regional policy in Latvia still is one of the most important challenges because of unique progress of regions in Latvia. Although in 2009 here an important administrative-territorial reform was realized, 
which resulted in 118 local governments instead of 548, it is still an issue - how to provide equal development of regions? It is completed also with factors like economic crises, relatively high unemployment rates in different regions. During the economic crises there was also a decrease in registration of new enterprises. Because of unemployment inhabitants tend to migrate abroad. Places of employment usually are created by private sector, so it is important to stimulate activity of entrepreneurship, because having a job is one of the main points to have prosperity in society.

The aim of this article is to assess business development in different regions from regional policy point of view. The main tasks are:

1. To make theoretical frame of regional policy role in regional economic and business development.

2. To analyze regional policy documents in Latvia.

3. To compare business development tendencies in regions of Latvia.

The object is entrepreneurship in regional policy. Research methods applied: monographic method, logical-constructive method, document analyze, statistical data analyze.

In recent years there have been many discussions in Latvia on how to get over the economic difficulties, but rarely these activities are linked to regional policy. A question is still open, whether the concept that entrepreneurship could solve economic and social problems works on regional level in Latvia.

\section{Regional policy and economic development}

Economic development of region is influenced by different factors - resources, human capital, and geographic conditions, social conditions, infrastructure, culture, production, innovations and science etc. In knowledge-based economies, regional networking, research and technology development and collective entrepreneuring appear as important key processes for future local development and attractiveness (Johannisson, Lindholm Dahlstrand, 2009).

It is known that there are significant differences between countries and regions. Consequently there is a discussion, what kind of activities are necessary and what kind of regional policy is appropriated. A new approach to regional policy in Europe is to not only try to solve social and economic differences, but also make stronger innovation process and society of knowledge.

Many countries devote a large part of their national budget to regional policies. These policies are designed to support the development of economically backward regions, substantially below the average of other regions. (Wiberg, 2011) A number of the regional initiatives set up by the EU and national European governments rely on distortionary financing schemes, which seek to reduce regional inequalities by encouraging relocation of activity to the periphery (Ulltveit-Moe, 2007).

Today the trend is to move from classic policy approaches in regional development towards a stronger orientation regarding the role that innovation could play for the regional economic development (Koschatzky, Stahlecker, 2010). Researchers consider that reasons for regional differences can be found on regional level, also reasons for different economic activity, business start ups (Saantarelli, Vivarelli, 2007) So it is a task for regional policy makers to provide conditions for economic growth to decrease regional disparities. For instance, governments both on national and international level spend money to support, for example, infrastructure project in poorer regions, thus trying to develop these territories. Many countries devote large amounts of money to improve their domestic infrastructure to make it easier and cheaper to transport goods, promote trade and increase the mobility of people (Gallo, 2010).

A common feature of regional policies is that they are designed to raise investment in poor regions by either a) directly granting subsidies for private investment or b) improving the regional infrastructure (Fuest, Huber, 2006). At the same time there is a contradiction, why it is necessary to support poor regions instead of investing money in successful area to make increased benefit. One of the reasons is to decrease migration from poorest territories to well developed regions. However C. Fuest and B. Huber (2006) think that from an economic perspective, the best way to reduce migration to rich regions is to tax migrants or to pay direct subsidies for staying in the poor regions.

However, there is also a sceptical view on performance of European regional policy. Some researchers even highlight that regional policy has had a negative rather than a positive impact, because still there are regional inequalities between EU member states and regions. Consequently, resources spent for the regional policy have not yielded the expected results.

One more component of regional policy in European countries is state aid to manufacturing and service sectors in the form of grants and subsidies. Public subsidy is aimed at influencing the regional allocation of investments and employment in order to increase competitiveness, selfsustaining growth and new employment in low income region (Bernini, Pellegrini, 2011). Also this is a disputable issue, whether it is the best way and in the result gives more benefit than amount of investment. For instance, C. Bernini and G. Pellegrini (2011), analyzing example of Italy, showed that the policy makers prefer to subsidize projects with higher employment, even if they are less productive. In addition, governments around the world use subsidies to attract firms to relatively deprived regions in the belief that they generate positive externalities. However, firms that potentially generate the largest spillovers may themselves benefit from co-location externalities, and thus be drawn towards current centres of activity (Devereux, Griffith, Simpson, 2006).

As the local environment influences the choices of entrepreneurs; entrepreneurial success influences the local economy (Glaeser, Rosenthal, Strange, 2010), also region influences entrepreneurs and vice versa. To choose a business place is one of the first tasks to do. A large empirical literature attempts to identify the determinants of start-ups, most of it focusing on the regional context (Gries, Naude, 2009). So regions have to prove their performance to be a good place for business. Business development in small towns and rural areas is also essential for the steady development of all country, and significant instrument to attract people to live outside metropolis. As I.Verheul, M. Carre, E.Santarelli (2009) mentioned, entrepreneurs in retailing and other small-scale services may be attracted to regions with high population density and high incomes, while entrepreneurs in manufacturing may be attracted to regions with low wages and well-developed infrastructure. Generally, the choice for 
a location is driven by regional opportunities and absence or presence of barriers to entry.

Main differences among the regions are access to resources, human capital, culture, political system, development level of economy. As business activity is strongly related to employment, also these two aspects have to be analyzed. The existence and persistence of regional disparities in the unemployment rate is a common problem of many European economies (Bande, Fernandez, Montuenga, 2008). Number of different factors is forming the attractiveness of the territory to start and develop business - social, economic, political, technological, regulatory, geographical and other conditions.

Also it is important to consider regional particularities, for instance, it is urban or rural territory. Y. Vaillant and E. Lafuente (2007) have mentioned that it is necessary to apply different business support mechanisms for urban and rural areas.

This approach also could be useful for regional policy. Small and medium cities often operate from narrower and more specialized industrial base but their economic future may be closely tied to the specific industries in which they have historically specialized (Wolfe, Bramwell, 2008). Focusing on one or more sectors of business, or even on large enterprise in the area, it makes advantages also for other enterprises, for instance, those providing services and goods. P. Devereux, R. Griffith and H. Simpson (2007) found that a region's existing industrial structure has an effect on the location of new entrants and grants do have a small effect in attracting plants to specific geographic areas, but firms are less responsive to government subsidies in areas where there are fewer existing plants in their industry.

At the same time it is a threat for local economy, because the area becomes dependent on this sector's successes and failures, which is highly risky. So a larger share of small and mediumsized businesses can make a local economy more flexible and less vulnerable to industry-specific shocks (Loveridge, Nizalov, 2007). Each business sector needs specific support, so it is necessary to identify region's development way to use the most appropriate support activities. As V. Harmaakorpi and V. Uotila mentioned, regions are strongly dependent on their history. The region's development trajectories are strongly path dependent. Therefore, it is impossible to build any kind of sustainable regional strategies without a thorough assessment of regional assets and resource configurations. It means that it is very important to use regional policy in step with the available resources.

All things considered, it is also assignment for regional policy to ensure activities suitable for region features, differences, advantages and disadvantages. Regions are considered to be strongly path-dependent entities needing to create new, even radical, paths to stay competitive in a rapidly changing world (Harmaakorpi, Uotila, 2006). As B.Johannisson and A.Lindholm Dahlstrand (2009) mentioned, both entrepreneurship and regional development are at present popular subjects in the policy-making European Community as well as in the global academic research community. There is also a tendency to use traditional instruments and methods both for regional and entrepreneurship development; consequently it is a more serious issue to evaluate previous activities. Besides, in Europe 2010 strategy all three priorities (smart growth, sustainable growth and inclusive growth) are closely linked to regional policy issues and regional development.

\section{Regional policy documents and entrepreneurship as a component in its in Latvia}

Logical basis of choosing instruments for regional development is political viewpoint. Instruments chosen by each country are indicatives of their regional policy.

In Latvia regional policy is developing since recovery of independence in $1990^{\text {th }}$. The first document about regional development policy was established in 1995 - it was a framework for regional development policy. Later, in 2002 there was also adopted "Regional development Law" and it is still operative with a number of changes. In Regional development Law there a definition is given of regional development and in this case it means beneficial change in social and economic situation in all country or in its separate parts. But regional policy is defined as government policy and focused activities to promote regional development, by coordinating development of industries according to the development priorities of separate parts of country and providing direct support to promote progress of a certain area. In the law a principle to consider each territory's characteristic features and possibilities is emphasized. Fundamental principles of regional development planning, mentioned in the "Regional development Law", are: concentration, programming, partnership, complementarities, publicity, principle of subsidiarity and sustainability. Regional development Law determines institutional structure of regional planning and policy implementation. These principles and institutional framework also influence development of entrepreneurship in all regions. It is a positive aspect that in this law there are aspirations to consider differences and characteristics of several regions included. On the other hand it also encourages defining of features, opportunities and main industries in each region and it is not an effortless issue.

Together with "Regional Development Law" there was also developed a "Spatial Planning Law" (2002); which is still operative with a number of changes. The aim of this law is to promote sustainable and balanced development of the country through effective spatial planning system. This law has also defined principles of territory planning sustainability, combination of interests, diversity, detalization, free competition, continuity and succession, publicity. Also tasks of territory planning are defined in „Spatial Planning Law" and some of them are related to entrepreneurship, for instance, to create favourable conditions for business developments and investment attraction. Consequently, there are accentuated needs and demands of entrepreneurship development. However, in the „Spatial Planning Law“ mostly there are institutional framework, responsibilities and procedure of planning process defined. Spatial planning has an important role in local governments, so support to business infrastructure development is highly dependent on municipalities. To coordinate all interested parties to consider territory's development is also a very specific and complicated process for the local governments, consequently it takes a long time and also skills and abilities necessary for administrators of the local governments.

Therefore, based on the "Spatial Planning Law“, „Local municipality territory spatial planning regulations" 
(2009) were drafted out. It is a new advantage for local governments to evaluate development of their territory after administrative-territorial reform (ended in 2009) and create new planning documents on local level, taking into account the new administrative divisions. New administrative areas most frequently were created by uniting two or more municipalities. Municipal Land spatial planning regulation defines that municipalities have to determine territory plan for the period of twelve years. This plan should be a great guide for entrepreneurs interested to start or develop a business in this municipality. To create such plan local governments have to have clear vision for territory's development in a long term.

To evaluate and determine resources on a broad scale, there are also „Regulations for the Spatial Planning Region“ (2005) in Latvia. These instructions define that, creating this plan, it is necessary to evaluate both resources, its perspective of development in all region and functional link with other regions and neighbouring country. Law demands to have a perspective on development of the region for a 20 year period. Guidelines of this plan are recommendations for local municipality development programmes and spatial development.

Resuming planning document hierarchy in Latvia, it is possible to divide regulation of planning system in three levels: national level, regional level and local level. Controversial is ability and performance of collaboration between all involved parties in this planning process. After the administrative territorial reform, controversies about necessity to strengthen the regional level in administrative way have intensified. The first part was an administrative view to regional policy, but it is also important to look at it in a conceptual way. In 2004 Cabinet of Ministers affirmed Conception of Regional policy, which is a long term document and it includes fundamental principles, aims, priorities and main directions of actions. In this document the most important problems in regional development are indentified: Latvia and its regions have low level of competitiveness compared to other regions in EU; significant differences in socio-economic development between and in planning regions, and tendency to become more and more unequal; low quality infrastructure unattractive to business and also living environment; Riga (the capital of Latvia) has a low level of competitiveness comparing with other European capitals. The reasons identified are: problems with coordinating industry development policy and harnesses to harmonize it with priorities of regional planning; lack of local and EU regional development support instrument interface; slow process of administrative-territorial reform and insignificant local government support instruments. Established aims are related to the defined problems. And one of the aims is to create equal preconditions in all regions for developing entrepreneurship to promote balanced progress of all country.

Also in 2006 a medium-term planning document "Latvia National Development Plan 2007-2013" was accepted, in which regional development issues were emphasized. In this development plan Latvia is seen as a polycentric development country. The aim is to have a favourable environment both for business and living. One of the tasks to improve region and local level function was to implement regional reform by creating regions and regional local governments capable of economic development. Reform was implemented, but there are still discussions taking place whether it was a successful one on both administrative and economical levels. As the next planning period in Europe Union will commence in 2014, politicians are already developing a new plan to provide successful planning of European funds.

In recent years there have been many discussions about development course for Latvia. Consequently, in 2010 by Saeima, the Latvian Parliament, was developed and approved a long-term planning document "Sustainable Development Strategy of Latvia until 2030". Now it is the main strategic planning document in Latvia, and it also refers to the regional policy and planning documents. In 2030 for Latvia one of the accents is interaction of rural-urban territories, to provide a balanced development - "regardless of the geographical location, the competitiveness and attraction of territories will be determined by the ability to offer qualitative and attractive living environment, as well as wide range of public services". The spatial development perspective puts emphasis on the three main aspects: a) accessibility and mobility possibilities, b) settlement as the economic development, human life and work environment, c) spaces of national interest - unique specific territories, significant for the development of the whole country. In this vision of development a significant role is given to spatial planning to provide infrastructure, public service, communications, energy, sustainable resource application. All these factors are important also for providing favourable environment for entrepreneurship.

\section{Entrepreneurship development tendencies in the regions of Latvia}

In Latvia there are five planning regions - Rīga, Vidzeme, Kurzeme, Zemgale and Latgale. But there are five statistical regions - Rīga, Pierīga, Kurzeme, Zemgale, Vidzeme and Latgale. By area the largest region is Vidzeme $(23.6 \%$ of territory of Latvia), but the most populated area is Rìga, where $48.6 \%$ of all inhabitants live. Riga is the smallest region by territory. Riga has the highest density of population - it is three times bigger than in the average number in Latvia. Data of survey "Development of Regions in Latvia 2009" show that during the five year period the greatest share of the total reduction of Latvian population was in Latgale region - 24.4 thousand. In region of Riga the number of inhabitants had even grown by 2.1 thousand people, while in the other regions it has reduced: in Vidzeme - by 11.4 thousand, in Kurzeme -by 10.4 thousand and in Zemgale - by 7.7 thousand people. Here is some of the data, that reflect the problems of unbalanced development and that also influences entrepreneurship environment.

There are also statistical evidence problems existing in socioeconomic development. Data of Statistics Board of Latvia shows that a great part of gross domestic product (GDP) is created in Riga - more than a half. This also indicates that development of regions is unequal. During the last years there is a decrease in GDP part of Riga region (from $57.3 \%$ in 2005 to $54.1 \%$ in 2008), but it is still significant (Table 1). The smallest part of GDP is created in Vidzeme (6.6\% in 2008) and Zemgale (7.6 \% in 2008). 
Table 1. GDP of statistical regions in Latvia (data of Statistics Board of Latvia)

\begin{tabular}{|l|c|c|c|c|c|c|c|c|}
\hline \multirow{2}{*}{ Rear } & \multicolumn{2}{|c|}{2005} & \multicolumn{2}{c|}{2006} & \multicolumn{2}{c|}{2007} & \multicolumn{2}{c|}{2008} \\
\cline { 2 - 9 } & $\begin{array}{c}\text { Total, LVL } \\
\text { thsd. }\end{array}$ & $\begin{array}{c}\text { Total, } \\
\text { proportion, } \\
\%\end{array}$ & $\begin{array}{c}\text { Total, LVL } \\
\text { thsd. }\end{array}$ & $\begin{array}{c}\text { Total, } \\
\text { proportion, } \\
\%\end{array}$ & $\begin{array}{c}\text { Total, LVL } \\
\text { thsd. }\end{array}$ & $\begin{array}{c}\text { Total, } \\
\text { proportion, } \\
\%\end{array}$ & $\begin{array}{c}\text { Total, LVL } \\
\text { thsd. }\end{array}$ & $\begin{array}{c}\text { Total, } \\
\text { proportion, } \\
\%\end{array}$ \\
\hline Ríga & 5190886 & 57.3 & 6174398 & 55.3 & 8036228 & 54.4 & 8749588 & 54.1 \\
\hline Pierīga & 1008529 & 11.1 & 1467991 & 13.1 & 1818255 & 12.3 & 2056433 & 12.7 \\
\hline Vidzeme & 563908 & 6.2 & 733130 & 6.6 & 990399 & 6.7 & 1065875 & 6.6 \\
\hline Kurzeme & 965196 & 10.7 & 1149313 & 10.3 & 1517697 & 10.3 & 1688246 & 10.4 \\
\hline Zemgale & 629684 & 7 & 805037 & 7.2 & 1180164 & 8 & 1237667 & 7.6 \\
\hline Latgale & 691460 & 7.6 & 831952 & 7.4 & 1219612 & 8.2 & 1358320 & 8.4 \\
\hline
\end{tabular}

Non-financial investments are one of the measures that shows economic growth and potential of territories. Data of Statistics Board of Latvia shows that comparing non-financial investments, it is seen that Rīga and Pierīga obtain most of the financial investments (Table 2). In 2009 there was a decrease in non-financial investments in all regions. It is explained by economic crises. In $200969 \%$ of all non-financial investments were in statistical regions of Rīga and Pierīga which is Rìga planning region. In Kurzeme $-11 \%$, Zemgale -7 and both in Vidzeme and Latgale it was $6 \%$. These figures show inequality of regional development as well. It also influences development of entrepreneurship in different regions.

Table 2. Dynamics of non-financial investments in the statistic regions from 2006 to 2009, in comparative prices of 2009, LVL million (data of Statistics Board of Latvia)

\begin{tabular}{|l|c|c|c|c|}
\hline Region/Year & $\mathbf{2 0 0 6}$ & $\mathbf{2 0 0 7}$ & $\mathbf{2 0 0 8}$ & $\mathbf{2 0 0 9}$ \\
\hline Rīga & 2131.5 & 2198.8 & 2431.7 & 1618.8 \\
\hline Pierīga & 776 & 973.4 & 663.8 & 397 \\
\hline Vidzeme & 310.5 & 291 & 284.4 & 185.4 \\
\hline Kurzeme & 480.4 & 479.3 & 506.8 & 334.3 \\
\hline Zemgale & 364.5 & 381.9 & 324 & 211.5 \\
\hline Latgale & 262.5 & 289 & 261.1 & 185.6 \\
\hline
\end{tabular}

Statistical data (by Lursoft) shows that $68.5 \%$ of enterprises are registered in Rīga. In Kurzeme there are 9.1\%, Latgale- $4.8 \%$, Zemgale $-8.0 \%$, Vidzeme $-9.5 \%$ of enterprises (Table 3). These numbers also confirm conclusions made before, that region of Riga is a great influence to economic situation of Latvia and it is the most powerful region and differences with the other regions are significant.

Table 3. Registered enterprises in the regions of Latvia (authors' construction by data of Latvian IT company Lursoft)

\begin{tabular}{|l|c|c|}
\hline Region & Enetrprises & \% \\
\hline Rīga & 7068 & 9.1 \\
\hline Pierīga & 53105 & 68.5 \\
\hline Vidzeme & 3742 & 4.8 \\
\hline Kurzeme & 6209 & 8.0 \\
\hline Zemgale & 7400 & 9.5 \\
\hline Latgale & 77524 & 100.0 \\
\hline
\end{tabular}

This analysis demonstrates the significant economic differences between regions of Latvia. Coherence between region development and activity of entrepreneurship is also noted. It demonstrates that supporting development of entrepreneurship and motivating people to start their own business, also providing suitable business environment and successful realization of support activities could also be a useful instrument of regional policy. Still there is a question, what kind of activities are the best to provide progress of entrepreneurship in all regions. It is important to continue research and evaluation with a goal to find the best solution for each region.

Table 4. The number of enterprises per 1000 inhabitants in the planning regions (authors' construction by data of Latvian IT company Lursoft and Statistics Board of Latvia)

\begin{tabular}{|l|c|c|c|}
\hline Region & Enterprises & Population & $\begin{array}{c}\text { Enterprises } \\
\text { per 1000 } \\
\text { inhabitants }\end{array}$ \\
\hline Rīga & 53105 & 1095706 & 48.47 \\
\hline Vidzeme & 7400 & 233570 & 31.68 \\
\hline Kurzeme & 7068 & 299506 & 23.60 \\
\hline Zemgale & 6209 & 279809 & 22.19 \\
\hline Latgale & 3742 & 339783 & 11.01 \\
\hline
\end{tabular}

\section{Conclusions}

During the recent years a concept that has become more and more popular is that entrepreneurship is a way to solve social and economic problems. Consequently, support to business is also one of the most popular points in development policies, also regional development. While there is an understanding that support for business is important on all levels, still there is a questions to answer, for instance, what kind of support activities are the most beneficial? Also an important issue to address is how to get the most advantage by investing as little as possible - how to use resources carefully and efficiently.

In Latvia both regional policy and entrepreneurship has become an actual issue lately - during the last 20 years, however, regional policy documents both on national and local level are provided, but in practice they are not successful, because differences between regions, their development are significant. Not only indicators of development are different but also different activity of entrepreneurship is observed. By analyzing and comparing statistic data, it is observed that in region with lower activity of business also other indicators are lower than in regions with higher entrepreneurship activity. 


\section{References}

Bande, R., Fernandez, M., Montuenga, V. (2008) Regional unemployment in Spain: Disparities, business cycle and wage setting. Labour Economics, Vol. 15, pp. 885-914

Barkley, D.L. (2008) Evaluations of Regional Competitiveness: Making a Case for Case Studies, The Review of Regional Studies, Vol. 38, No 2, pp. 121-143

Bernini, C., Pellegrini G. (2011) How are growth and productivity in private firms affected by public subsidy? Evidence from a regional policy. Regional Science and Urban Economics, Vol. 41, pp. 253-265

Conception of Regional policy (2004) On-line: http://www. likumi.lv/doc.php?id=86678

Data of Statistics Board of Latvia. On-line: http://www.csb. gov.lv/en/dati/statistics-database-30501.html-0

Development of Regions in Latvia 2009 (2010) On-line: http://www.vraa.gov.lv/uploads/Development_of_ Regions_2009.pdf

Devereux, M.P., Griffith, R., Simpson, H. (2006) Firm location decisions, regional grants and agglomeration externalities. Journal of Public Administration, Vol. 91, pp. 413-435

Europe 2010 strategy. On-line: http://europa.eu/press_room/ pdf/complet_en_barroso__007__europe_2020_-_en version.pdf

Fuest, C., Huber, B. (2006) Can regional policy in a federation improve economic efficiency? Journal of Public Economics, Vol. 90, pp. 499-511

Gallo, F. (2010) Resisting economic integration when industry location is uncertain. EuropeanEconomic Review, Vol. 54, pp. 467-482

Glaeser E.L., Rosenthal S.S., Strange W.C. (2010) Urban economics and entrepreneurship. Journal of Urban Economics, Vol 67, pp. 1-14

Gries, T., Naude, W. (2009) Entrepreneurship and regional economic growth: towards a general theory of start-ups. Innovation - The European Journal of Social Science Research, Vol. 22, No 3, pp. 309-328

Gross Domestic product by statistical region, city and district. On-line: http://data.csb.gov.lv/DATABASEEN/ ekfin/Annual $\% 20$ statistical $\% 20$ data/02.\%20Gross $\% 20$ domestic\%20product/02.\%20Gross\%20domestic\%20 product.asp

Hackler, D., Mayer, H. (2008) Diversity, Entrepreneurship, and the Urban Environment, Journal of Urban Affairs, Vol. 30, No3, pp. 273-307

Harmaakorpi, V., Uotila, T. (2006) Building region visionary capability. Futures research in resource-based regional development. Technological Forecasting \& Social Change, Vol. 73, pp. 778-792

Johansson, A.W. (2009) Regional Development by Means of Broadened Entrepreneurship, European Planning Studies, Vol. 17, No 8, pp. 1205-1222

Johannson, A.W., Dahlstrand, A. L. (2009) Bridging the Functional and Territorial Views on Regional Entrepreneurship and Development: The Challange, the Journey, the Lessons. European Planning Studies, Vol. 17, No 8, pp. 1105-1115
Koschatzky, K., Stahlecker, T. (2010) A new Challenge for Regional Policy-Making in Europe? Chances and Risks of the Merger Between Cohesion and Innovation Policy, European Planning Studies, Vol. 18, No 1, pp. 7-25

Loveridge S., Nizalov D. (2007) Operationalizing the Entrepreneurial Pipeline Theory: An Empirical Assessment of the Optimal Size Distribution of Local Firms, Economic Development Quarterly, Vol. 21, pp. 244-262

Lursoft statistics about enterprise by regions. On-line: https://www.lursoft.lv/estadistic?act=UR_STAT\&id=511 $\&$ tablereorder $=$ yes\&tableorder $=1 \&$ tablesequence $=\mathrm{D}$

Municipal territory spatial planning regulations (2009) Online: http://www.likumi.lv/doc.php?id=198901\&from=off

National development plan 2007-2013 (2006) On-line: http://www.nap.lv/eng/

Non-financial investment by statistical region. On-line: http://data.csb.gov.lv/DATABASEEN/ekfin/Annual $\% 20$ statistical\%20data/05.\%20Investment/05.\%20Investment.asp

Regional development Law (2002) On-line: http://www. likumi.lv/doc.php?id=61002

Regulations for the Spatial Planning Region (2005) On- line: http://www.likumi.lv/doc.php?id=106360\& from $=$ off

Resident population by statistical region. On-line: http://data. csb.gov.lv/Dialog/Saveshow.asp

Santarelli, E., Vivarelli, M. (2007) Entrepreneurship and the process of firms'entry, survival and growth. Industrialand Corporate Change, Vol 16, p 455-488

Spatial Planning Law (2002) On-line: http://www.likumi.lv/ doc.php?id=63109

Sustainable Development Strategy of Latvia until 2030 (2010) On-line: http://www.latvija2030.lv/upload/ latvija2030_en.pdf

Ulltveit-Moe, K.H. (2007) Regional policy design: An analysis of relocation, efficiency and equity. European Economic Review. Vol. 51, pp. 1443-1467

Vaillant Y, Lafuente E. (2007) Do different institutional frameworks condition the influence of local fear of failure and entrepreneurial examples over entrepreneurial activity? Entrepreneurship \& Regional Development, Vol 19, pp. 313-337

Verheul I., Carre M., Santarelli E. (2009) Regional Opportunities and Policy Initiatives for New Venture Creation, International Small Business Journal, Vol 27, pp. 608-625

Wiberg, M. (2011) Political participation, regional policy and the location of industry. Regional Science and Urban Economics. On-line: doi:10.1016/j. regsciurbeco.2011.03.00

Wolfe D. A., Bramwell A. (2008) Innovation, creativity and governance: Social dynamics of economic performance in city-regions. Innovation: Management, Policy \& Practice, Vol. 10, pp. 170-182

The article has been reviewed.

Received in April, 2011; accepted in June, 2011. 